\title{
Design and Implementation of a Multi-Phase Induction Machine Operating in generating Mode for Power Generation
}

\author{
Alok Kumar Mohanty \\ Department of \\ Electrical and Electronics \\ Engineering \\ NIT, Jamshedpur, \\ Jharkhand, India
}

\author{
K.B. Yadav \\ Department of \\ Electrical and Electronics \\ Engineering \\ NIT, Jamshedpur, \\ Jharkhand, India
}

\begin{abstract}
Self-excited induction generators are increasingly being used in remote areas to generate electrical power from both conventional and nonconventional energy sources. This paper investigates a multi-phase self excited induction generator designed for its six-phase operation. Evaluations were made out on the basis of the machine performance which includes voltage and current characteristics at different conditions. The model used for analyzing the machine behavior has two three phase winding sets. In this paper the analytical modeling of a self excited induction generator operating in six phase mode has been made and the analysis of the machine has been carried out with symmetrical phase displacement between the six stator windings. The dynamics of the self excitation process of the six phase self-excited induction generator has been made which was simulated and analyzed.
\end{abstract}

\section{Keywords}

Multiphase; Self-excited induction generator; Analysis.

\section{INTRODUCTION}

The increasing concern of the environment, especially the greenhouse effects, has motivated the world towards exploring the use of renewable energy sources and reduces dependency on fossil fuels. Most of the renewable energy sources, such as wind, mini-hydro, etc. are usually available in remote areas. A self-excited induction generator is found to be very suitable to generate electrical power in remote areas from renewable energy sources, such as wind and mini-hydro turbines [1]. A SEIG has many advantageous features over its counterpart synchronous generator. These features are low cost, high reliability, maintenance and operational simplicity, rugged construction, brushless operation, protection against overloads and short circuits, etc. Even though a SEIG is very suitable for wind and mini-hydro plants, it can also efficiently be used with prime movers driven by other energy sources, such as diesel, biogas, natural gas, gasoline, etc.

In comparison with three phase machines, multiphase machines are considered as an alternative for variable speed applications. As there is an increase in demand of energy demand during the last few decades, the use of renewable energy sources has become essential and as a result of this, the investigation of the self-excited induction generator has gained importance as it is particularly for renewable power generation applications $[1,2,4]$. The application of selfexcited induction generator due to its decreased unit cost, simple to operate and ease in maintaining is most suited in renewable energy systems. The advantages of self excited induction generator are no separate source for excitation is required, protection from overload, good transient performance,

simple and robust construction and ease in maintenance. As the rating of power is increased and high reliability requirements, research in the area of multi-phase machines have been increasing.

In this paper the analytical modeling of a self excited induction generator operating in six phase mode has been made and the analysis of the machine has been carried out with symmetrical phase displacement between the six stator windings. The mathematical model is implemented for connection of pure resistive load with certain value of capacitor that is connected across self excited induction generator operating in six phase mode. The dynamics of the self excitation process of the six phase self-excited induction generator has been made which was simulated and analyzed.

\section{SELF-EXCITATION PHENOMENON OF INDUCTION GENERATOR}

The self-excitation phenomenon of an induction machine is still under considerable attention. When a standalone self excited induction generator is driven by a prime mover, the residual magnetism in the rotor of the machine induces an EMF in the stator windings at a frequency proportional to the rotor speed. This EMF is applied to the capacitors connected to the stator terminals and causes reactive current to flow in the stator windings. Hence a magnetizing flux in the machine is established. The ultimate magnitude of the voltage in the stator windings is limited by the saturation of the magnetic path within the machine. The induction machine is then capable of operating as a generator in isolated locations without a grid supply $[2,3]$. When the induction machine is self-excited and connected to the load, the steady-state voltage is generated by the SEIG, the value of the self-excitation capacitance, speed, machine parameters and terminal load. When the load and speed of Self excited induction generator changes, the magnitude for lagging VARs to maintain a constant magnitude of alternating voltage across the machine terminals also changes.

For the stand-alone mode of operation of the induction generator, it is essential for the induction generator to be operated in the saturation region. There is intersection between the magnetization curve and the capacitor reactance line, as well as output voltage stability under load. During noload operation of the machine, the capacitor current $\mathrm{Ic}=\mathrm{VI} / \mathrm{Xc}$ must be equal to the magnetizing current $\mathrm{Im}=\mathrm{V} 1 / \mathrm{Xm}$. The voltage V1 is a function of $\mathrm{Im}$; linearly rise until the saturation of the magnetic path is reached. The frequency of the self- 
excited generator is, $f=1 /(2 \pi \mathrm{CXm})$ and $\omega=2 \pi \mathrm{f}$ where $\mathrm{C}$ is selfexciting capacitance.

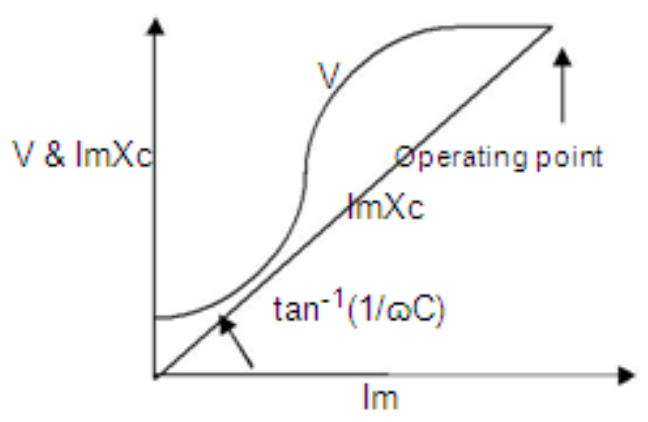

Fig1.Stable operation of a self-excited induction generator

\section{MULTIPHASE INDUCTION GENERATOR}

Machines having more than three phases as in a conventional machine are referred to as a high phase order machine on multiphase machines [4, 5, 6]. Multiphase machines have certain advantages over the conventional three phase machines such as capability to start and run even one or two of its stator phase open or short circuited, lower current per phase without increasing voltage per phase, increased power in the same frame, for a given machine output power utilization of more than three phase enables splitting of power across larger number of inverter legs. Additional number of phase added to the machine also brings additional freedom for improvements in the system. Basically a multiphase induction machine can have two different types of configurations.

a) Split phase electrical machines-Split phase electrical machines consists of two similar stator winding sharing the same magnetic circuit. Such a construction has made it possible to extend the power range by sharing the total power into two parts. Usually a split phase machine is built by splitting the phase belt of a conventional three phase machine into two equal parts with phase separation of $30^{\circ}$ electrical. By using this arrangement for the same air gap flux, the inverter voltage can be reduced by half as compared to the three phase machines since the number of turns is reduced.

b) Dual stator electrical machines-This type of electrical machines consists of two separate independent stator winding sharing the same magnetic circuit,A six different voltage magnitudes could be used for each winding group.One set of the stator winding is used for electromechanical power conversion while the second set of stator winding can be used for excitation purpose.In a dual stator electrical machines, the power can be extended without the need to use multilevel conveters.

In a conventional three phase machine, the conductors are distributed in slots symmetrically for each phase group and the conductors belonging to each phase group are series whereas in a multiphase induction machine we subdivide each phase group of a usual three phase machine into equal subgroups by disconnecting the series connection of the conductors. More number of three phase groups can be obtained from the same machine. In this way multiphase machine such as six-phases, nine- phases, twelve- phases, fifteen-phases, eighteen-phases can be produced from a three phase machine by subdividing the phase groups into two, three, four subgroups respectively.

\section{MATHEMATICAL MODELLING OF A SIX-PHASE SELF EXCITED INDUCTION GENERATOR}

A self excited induction generator operating in six phase mode has two stator winding sets namely abc and xyz, whose magnetic axes are displaced by an angle $\alpha[7]$. The windings of each three-phase set are distributed and the axes are displaced $120^{\circ}$ apart from each other. The three-phase rotor windings ar, br, cr as shown in Fig. 1 are also sinusoidally distributed and has axes have an separation of $120^{0}$.

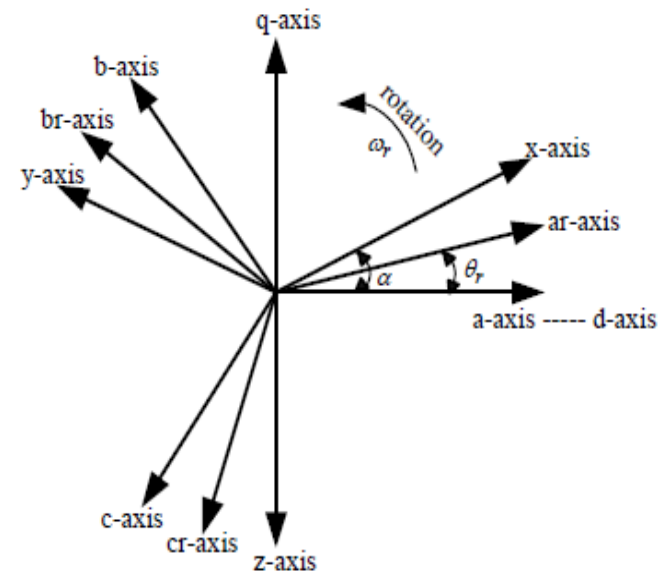

Fig.2.Phasor diagram representation of stator and rotor windings of induction generator operating in six phase mode

The equations for the self excited induction generator operating in six phase mode, describes the behavior of a multi-phase machine, it is assumed that the neutral of both the stator winding sets are separate so that if a fault occurs in one set of the stator windings it does not propagate to the other set. The following voltage equations are written for a multi- phase induction machine $[8,9]$

where,

$\mathrm{v}_{\mathrm{q} 1}=-\mathrm{r}_{1} \mathrm{i}_{\mathrm{q} 1}+\omega_{\mathrm{k}} \lambda_{\mathrm{d} 1}+\mathrm{p} \lambda_{\mathrm{q} 1}$
$\mathrm{v}_{\mathrm{d} 1}=-\mathrm{r}_{1} \mathrm{i}_{\mathrm{d} 1}+\omega_{\mathrm{k}} \lambda_{\mathrm{q} 1}+\mathrm{p} \lambda_{\mathrm{d} 1}$
$\mathrm{v}_{\mathrm{q} 2}=-\mathrm{r}_{2} \mathrm{i}_{\mathrm{q} 2}+\omega_{\mathrm{k}} \lambda_{\mathrm{q} 2}+\mathrm{p} \lambda_{\mathrm{q} 2}$
$\mathrm{v}_{\mathrm{d} 2}=-\mathrm{r}_{2} \mathrm{i}_{\mathrm{d} 2}+\omega_{\mathrm{k}} \lambda_{\mathrm{d} 1}+\mathrm{p} \lambda_{\mathrm{d} 2}$
$\mathrm{r}_{\mathrm{r}} \mathrm{i}_{\mathrm{qr}}+(\omega \mathrm{k}-\omega \mathrm{r}) \lambda_{\mathrm{dr}}-\mathrm{p} \lambda_{\mathrm{qr}}=0$
$\mathrm{r}_{\mathrm{r}} \mathrm{i}_{\mathrm{dr}}+(\omega \mathrm{k}-\omega \mathrm{r}) \lambda_{\mathrm{qr}}-\mathrm{p} \lambda_{\mathrm{dr}}=0$

The speed of the frame taken for reference, $\omega_{k}$, differentiation with respect to time is denoted by $\mathrm{p}$,the rotor speed is denoted by $\omega_{r}$. Here the rotor winding magnitudes are referred to stator windings. 
The values for stator windings and rotor winding linkages are as follows

$$
\begin{aligned}
& \mathrm{L}_{\mathrm{m}}\left(\mathrm{i}_{\mathrm{qr}}-\mathrm{i}_{\mathrm{q} 1}-\mathrm{i}_{\mathrm{q} 2}\right)-\mathrm{L}_{11} \mathrm{i}_{\mathrm{q} 1}-\mathrm{L}_{\mathrm{lm}}\left(\mathrm{i}_{\mathrm{q} 1}+\mathrm{i}_{\mathrm{q} 2}\right)=\lambda_{\mathrm{q} 1} \\
& \mathrm{~L}_{\mathrm{m}}\left(\mathrm{i}_{\mathrm{dr}}-\mathrm{i}_{\mathrm{d} 1}-\mathrm{i}_{\mathrm{d} 2}\right)-\mathrm{L}_{11} \mathrm{i}_{\mathrm{d} 1}-\mathrm{L}_{\mathrm{lm}}\left(\mathrm{i}_{\mathrm{d} 1}+\mathrm{i}_{\mathrm{d} 2}\right)=\lambda_{\mathrm{d} 1} \\
& \mathrm{~L}_{\mathrm{m}}\left(\mathrm{i}_{\mathrm{qr}}-\mathrm{i}_{\mathrm{q} 1}-\mathrm{i}_{\mathrm{q} 2}\right)-\mathrm{L}_{11} \mathrm{i}_{\mathrm{q} 2}-\mathrm{L}_{\mathrm{lm}}\left(\mathrm{i}_{\mathrm{q} 1}+\mathrm{i}_{\mathrm{q} 2}\right)=\lambda_{\mathrm{q} 2} \\
& \mathrm{~L}_{\mathrm{m}}\left(+\mathrm{i}_{\mathrm{dr}}-\mathrm{i}_{\mathrm{d} 1}-\mathrm{i}_{\mathrm{d} 2}\right)-\mathrm{L}_{\mathrm{l} 1} \mathrm{i}_{\mathrm{d} 2}-\mathrm{L}_{\mathrm{lm}}\left(\mathrm{i}_{\mathrm{d} 1}+\mathrm{i}_{\mathrm{d} 2}\right)=\lambda_{\mathrm{d} 1} \\
& \mathrm{~L}_{\mathrm{m}}\left(\mathrm{i}_{\mathrm{qr}}-\mathrm{i}_{\mathrm{q} 1}-\mathrm{i}_{\mathrm{q} 2}\right)-\mathrm{L}_{1 \mathrm{r}} \mathrm{i}_{\mathrm{qr}}=\lambda_{\mathrm{qr}} \\
& \mathrm{L}_{\mathrm{m}}\left(\mathrm{i}_{\mathrm{dr}}-\mathrm{i}_{\mathrm{d} 1}-\mathrm{i}_{\mathrm{d} 2}\right)-\mathrm{L}_{1 \mathrm{r}} \mathrm{i}_{\mathrm{dr}}=\lambda_{\mathrm{dr}} \\
& (\mathrm{N} 1 / \mathrm{N} 2) \mathrm{L}_{\mathrm{lm}}=\mathrm{L}_{\mathrm{lm}}{ }^{\prime}
\end{aligned}
$$

Where $\mathrm{N}_{1}$ and $\mathrm{N}_{2}$ are the number of turns in the two sets of stator winding Mutual leakage inductance is $\mathrm{L}_{\mathrm{lm}}$ between the stator winding sets of stator and $\mathrm{L}_{\mathrm{m}}$ is the mutual inductance between the stator and rotor

$$
\mathrm{Llm}=\mathrm{Llax} \cos \alpha+\mathrm{L} \text { lay } \cos (\alpha+2 \pi / 3)+\mathrm{Llaz} \cos (\alpha-2 \pi / 3)
$$
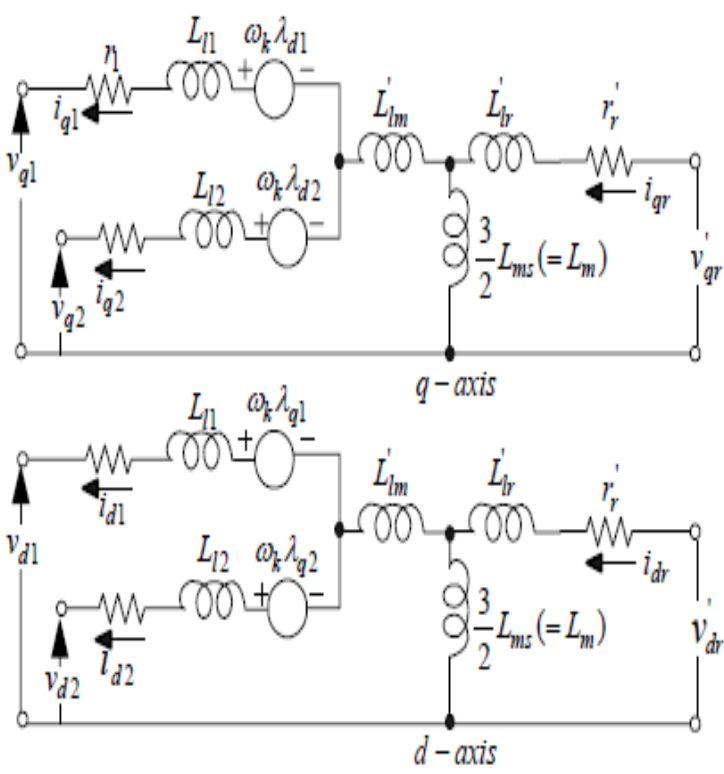

Fig.3.Circuit representation self excited induction generator in six phase operation

The current in both the sets of phases are out of phase with each other

$$
\begin{aligned}
& \lambda_{\mathrm{q} 1}=\int\left[\mathrm{v}_{\mathrm{q} 1}-\omega_{\mathrm{k}}\right. \\
& \left.\lambda_{\mathrm{d} 1}-\left(\mathrm{r}_{1} / \mathrm{L}\right)\left(\left(\mathrm{L}_{\mathrm{l} 2}+\mathrm{L}_{\mathrm{lm}}{ }^{\prime}\right) \lambda_{\mathrm{q} 1}-\mathrm{L}_{\mathrm{lm}}{ }^{\prime} \lambda_{\mathrm{q} 2}-\mathrm{L}_{\mathrm{l} 2} \lambda_{\mathrm{mq}}\right)\right] \\
& \left.\lambda_{\mathrm{q} 1}-\left(\mathrm{r}_{1} / \mathrm{L}\right)\left(\left(\mathrm{L}_{12}+\mathrm{L}_{\mathrm{lm}}{ }^{\prime}\right) \lambda_{\mathrm{d} 1}-\mathrm{L}_{\mathrm{lm}}{ }^{\prime} \lambda_{\mathrm{d} 2}-\mathrm{L}_{12} \lambda_{\mathrm{md}}\right)\right] \\
& \lambda_{\mathrm{d} 1}=\int\left[\mathrm{v}_{\mathrm{d} 1}+\omega_{\mathrm{k}}\right. \\
& \left.\lambda_{\mathrm{d} 2}-\left(\mathrm{r}_{2} / \mathrm{L}\right)\left(\left(\mathrm{L}_{11}+\mathrm{L}_{\mathrm{lm}}{ }^{\prime}\right) \lambda_{\mathrm{q} 2}-\mathrm{L}_{\mathrm{lm}}{ }^{\prime} \lambda_{\mathrm{q} 1}-\mathrm{L}_{11} \lambda_{\mathrm{mq}}\right)\right]
\end{aligned}
$$
(18)

$$
\begin{aligned}
& \lambda_{\mathrm{qr}}=\int\left[-\left(\omega_{\mathrm{k}}-\Phi_{\mathrm{r})} \lambda_{\mathrm{dr}}-\left(\mathrm{r}_{\mathrm{r}} / \mathrm{L}_{\mathrm{lr}}\right)\left(\lambda_{\mathrm{qr}}-\lambda_{\mathrm{mq}}\right)\right]\right. \\
& (19) \\
& \lambda_{\mathrm{dr}}=\int\left[-\left(\Phi_{\mathrm{k}}-\Phi_{\mathrm{r})} \lambda_{\mathrm{qr}}-\left(\mathrm{r}_{\mathrm{r}} / \mathrm{L}_{\mathrm{lr}}\right)\left(\lambda_{\mathrm{dr}}-\lambda_{\mathrm{md}}\right)\right]\right.
\end{aligned}
$$

where,

$\lambda_{\mathrm{mq}}=\mathrm{A}\left[\left(\mathrm{L}_{12} \lambda_{\mathrm{q} 1}+\mathrm{L}_{11} \lambda_{\mathrm{q} 2}\right) /(\mathrm{L})+\left(\lambda_{\mathrm{qr}} / \mathrm{L}_{\mathrm{rr}}\right)\right]$

$\lambda_{\mathrm{md}}=\mathrm{A}\left[\left(\mathrm{L}_{12} \lambda_{\mathrm{d} 1}+\mathrm{L}_{11} \lambda_{\mathrm{d} 2}\right) /(\mathrm{L})+\left(\lambda_{\mathrm{dr}} / \mathrm{L}_{1 \mathrm{r}}\right)\right]$

The torque magnitude of the six-phase induction generator is expressed as

$\mathrm{T}_{\mathrm{em}}=(\mathrm{P} / 2)\left(\mathrm{L}_{\mathrm{m}} / \mathrm{L}_{\mathrm{r}}\right)(3 / 2)\left[\left(\mathrm{i}_{\mathrm{q} 1}+\mathrm{i}_{\mathrm{q}} 2\right) \lambda_{\mathrm{dr}}-\left(\mathrm{i}_{\mathrm{d} 1}+\mathrm{i}_{\mathrm{d}} 2\right) \lambda_{\mathrm{qr}}\right]$

The dynamics of the rotor of the induction generator is given as

$\left(\omega_{\mathrm{r}} / \omega_{\mathrm{b}}\right)=\left[\left(1 / \omega_{\mathrm{b}}\right)(\mathrm{P} / 2)(1 / \mathrm{J})\left(\mathrm{T}_{\mathrm{em}}-\mathrm{T}_{\mathrm{sh}}\right)\right](1 / \mathrm{p})$

Where

the shaft torque is $\mathrm{T}_{\mathrm{sh}}$

the number of poles is diven by $\mathrm{P}$

the moment of inertia is $\mathbf{J}$

The base speed is wb

$\mathrm{L}_{\mathrm{r}}=\mathrm{L}_{\mathrm{lr}}+\mathrm{L}_{\mathrm{m}}$

The magnitude of $\mathrm{L}_{\mathrm{m}}$ depends on saturation

The magnetizing current $\mathrm{I}_{\mathrm{m}}$, is expressed by

$\mathrm{I}_{\mathrm{m}}=\sqrt{ }\left[\left(-\mathrm{i}_{\mathrm{q} 1}-\mathrm{i}_{\mathrm{q} 2}+\mathrm{i}_{\mathrm{qr}}\right)^{2}+\left(-\mathrm{i}_{\mathrm{d} 1}-\mathrm{i}_{\mathrm{d} 2}+\mathrm{i}_{\mathrm{dr}}\right)^{2}\right]$

$\mathrm{L}_{\mathrm{m}}=\mathrm{a}+\mathrm{b}+\mathrm{cI}_{\mathrm{m}}{ }^{2}+\mathrm{dI}_{\mathrm{m}}{ }^{3}$

(25)

Shunt Capacitor for excitation of the machine

The current and voltage equations of the capacitor are as follows:

$\mathrm{v}_{\mathrm{q} 1}=\int\left[\left(\mathrm{i}_{\mathrm{q} 1 \mathrm{c}} / \mathrm{C}_{\mathrm{sh} 1}\right)-\omega_{\mathrm{b}} \mathrm{d} 1\right]$

$\mathrm{v}_{\mathrm{d} 1}=\int\left[\left(\mathrm{i}_{\mathrm{d} 1 \mathrm{c}} / \mathrm{C}_{\mathrm{sh} 1}\right)+\omega_{\mathrm{b}} \mathrm{q} 1\right]$

$\mathrm{v}_{\mathrm{q} 2}=\int\left[\left(\mathrm{i}_{\mathrm{q} 2 \mathrm{c}} / \mathrm{C}_{\mathrm{sh} 2}\right)-\omega_{\mathrm{b}} \mathrm{v}_{\mathrm{d} 2}\right]$

$\mathrm{v}_{\mathrm{d} 2}=\int\left[\left(\mathrm{i}_{\mathrm{d} 2 \mathrm{c}} / \mathrm{C}_{\mathrm{sh} 2}\right)+\omega_{\mathrm{b}} \mathrm{v}_{\mathrm{q} 2}\right]$

Where $\mathrm{i}_{\mathrm{q} 1 \mathrm{c}}, \mathrm{i}_{\mathrm{d} 1 \mathrm{c}}, \mathrm{i}_{\mathrm{q} 2 \mathrm{c}}, \mathrm{i}_{\mathrm{d} 2 \mathrm{c}}$ are $q$ - and $d$ - axis components of currents, $\mathrm{C}_{\mathrm{Sh} 1}$ and $\mathrm{C}_{\mathrm{Sh} 2}$ connected across the two stator winding sets .

Capacitance required for the machine 
The magnitude of current in the series connected capacitor Cse 1 and Cse2 respectively are same as the load current. The voltage across the series capacitor is met by the load current.

$\int\left(\mathrm{i}_{\mathrm{q} 1 \mathrm{~L}} / \mathrm{C}_{\mathrm{Se}_{1}}\right)=\mathrm{v}_{\mathrm{q} 1 \mathrm{se}}$

(30)

$\int\left(\mathrm{i}_{\mathrm{d} 1 \mathrm{~L}} / \mathrm{C}_{\mathrm{Se}_{1}}\right)=\mathrm{v}_{\mathrm{d} 1 \mathrm{se}}$

$\int\left(\mathrm{i}_{\mathrm{q} 2 \mathrm{~L}} / \mathrm{C}_{\mathrm{Se}_{2}}\right)=\mathrm{v}_{\mathrm{q} 2 \mathrm{se}}$

$\int\left(\mathrm{i}_{\mathrm{q} 2 \mathrm{~L}} / \mathrm{C}_{\mathrm{Se}_{2}}\right)=\mathrm{v}_{\mathrm{q} 2 \mathrm{se}}$

Load voltage across the terminals

$\mathrm{vq} 1-\mathrm{vq} 1 \mathrm{se}=\mathrm{vLq} 1$

(34)

$\operatorname{vd} 1-\mathrm{vd} 1 \mathrm{se}=\mathrm{vLd} 1$

(35)

$v q 2-v q 2 s e=v L q 2$

$v q 2-v d 2 s e=v L d 2$

When resistive load is connected across the terminal of the generator, the load current (without series capacitor) isgiven by:

$\left(\mathrm{v}_{\mathrm{d} 1} / \mathrm{R} 1\right)=\mathrm{i}_{\mathrm{d} 1 \mathrm{~L}}$,

$\left(\mathrm{v}_{\mathrm{q} 1} / \mathrm{R}_{1}=\mathrm{i}_{\mathrm{q} 1 \mathrm{~L}}\right.$

(38)

$\left(\mathrm{v}_{\mathrm{d} 2} / \mathrm{R}_{2}\right)=\mathrm{i}_{\mathrm{d}} 2 \mathrm{~L}$,

$\left(\mathrm{v}_{\mathrm{q} 2} / \mathrm{R}_{2}\right)=\mathrm{i}_{\mathrm{q} 2} \mathrm{~L}$

Implementaion of Kirchoffs Current Law at terminals across the capacitor yeilds, the following current expressions

$$
\begin{gathered}
\mathrm{i}_{\mathrm{q} 1}-\mathrm{i}_{\mathrm{q} 1 \mathrm{~L}}=\mathrm{i}_{\mathrm{q} 1 \mathrm{c}}, \\
\mathrm{i}_{\mathrm{d} 1}-\mathrm{i}_{\mathrm{d} 1 \mathrm{~L}}=\mathrm{i}_{\mathrm{d} 1 \mathrm{c}} \\
(40) \\
\mathrm{i}_{\mathrm{q} 2}-\mathrm{i}_{\mathrm{q} 2 \mathrm{~L}}=\mathrm{i}_{\mathrm{q} 2 \mathrm{c}}, \\
\mathrm{i}_{\mathrm{d} 2}-\mathrm{i}_{\mathrm{d} 2 \mathrm{~L}}=\mathrm{i}_{\mathrm{d} 2 \mathrm{c}}
\end{gathered}
$$

Modeling of Load

$$
\begin{aligned}
& \mathrm{v}_{\mathrm{q} 1}=\int\left[\left(\mathrm{i}_{\mathrm{q} 1} / \mathrm{C}_{\mathrm{sh} 1}\right)-\left(\mathrm{v}_{\mathrm{q} 1} /\left(\mathrm{R}_{1} \mathrm{C}_{\mathrm{sh} 1}\right)\right)-\omega_{\mathrm{b}} \mathrm{v}_{\mathrm{d} 1}\right] \\
& \quad(42) \\
& \mathrm{v}_{\mathrm{d} 1}=\int\left[\left(\mathrm{i}_{\mathrm{d} 1} / \mathrm{C}_{\mathrm{sh} 1}\right)-\left(\mathrm{v}_{\mathrm{d} 1} /\left(\mathrm{R}_{1} \mathrm{C}_{\mathrm{sh} 1}\right)\right)+\omega_{\mathrm{b}} \mathrm{v}_{\mathrm{q} 1}\right] \\
& (43) \\
& \mathrm{v}_{\mathrm{q} 2}=\int\left[\left(\mathrm{i}_{\mathrm{q} 2} / \mathrm{C}_{\mathrm{sh} 2}\right)-\left(\mathrm{v}_{\mathrm{q} 2} /\left(\mathrm{R}_{2} \mathrm{C}_{\mathrm{sh} 2}\right)\right)-\omega_{\mathrm{b}} \mathrm{v}_{\mathrm{d} 2}\right] \\
& (44) \\
& \mathrm{v}_{\mathrm{d} 2}=\int\left[\left(\mathrm{i}_{\mathrm{d} 2} / \mathrm{C}_{\mathrm{sh} 2}\right)-\left(\mathrm{v}_{\mathrm{d} 2} /\left(\mathrm{R}_{2} \mathrm{C}_{\mathrm{sh} 2}\right)\right)+\omega_{\mathrm{b}} \mathrm{v}_{\mathrm{q} 2}\right]
\end{aligned}
$$

Where, $\mathrm{R}_{1}$ and $\mathrm{R}_{2}$ are the magnitudes of the load that are connected across the two stator windings.

\section{RESULTS AND DISCUSSIONS}

The simulation model of self-excited induction generator on six phase operation is implemented using MATLAB/Simulink platform. The following analysis was made:

(i) The current and voltage characteristics of self-excited induction generator operating in six phase mode at no-load condition.

(ii) The current and voltage characteristics of self-excited induction generator operating in six phase at resistive load condition. The simulation analysis an induction machine operating in six phase mode is done with the parameters as given in Appendix-I is used as a self-excited induction generator. 


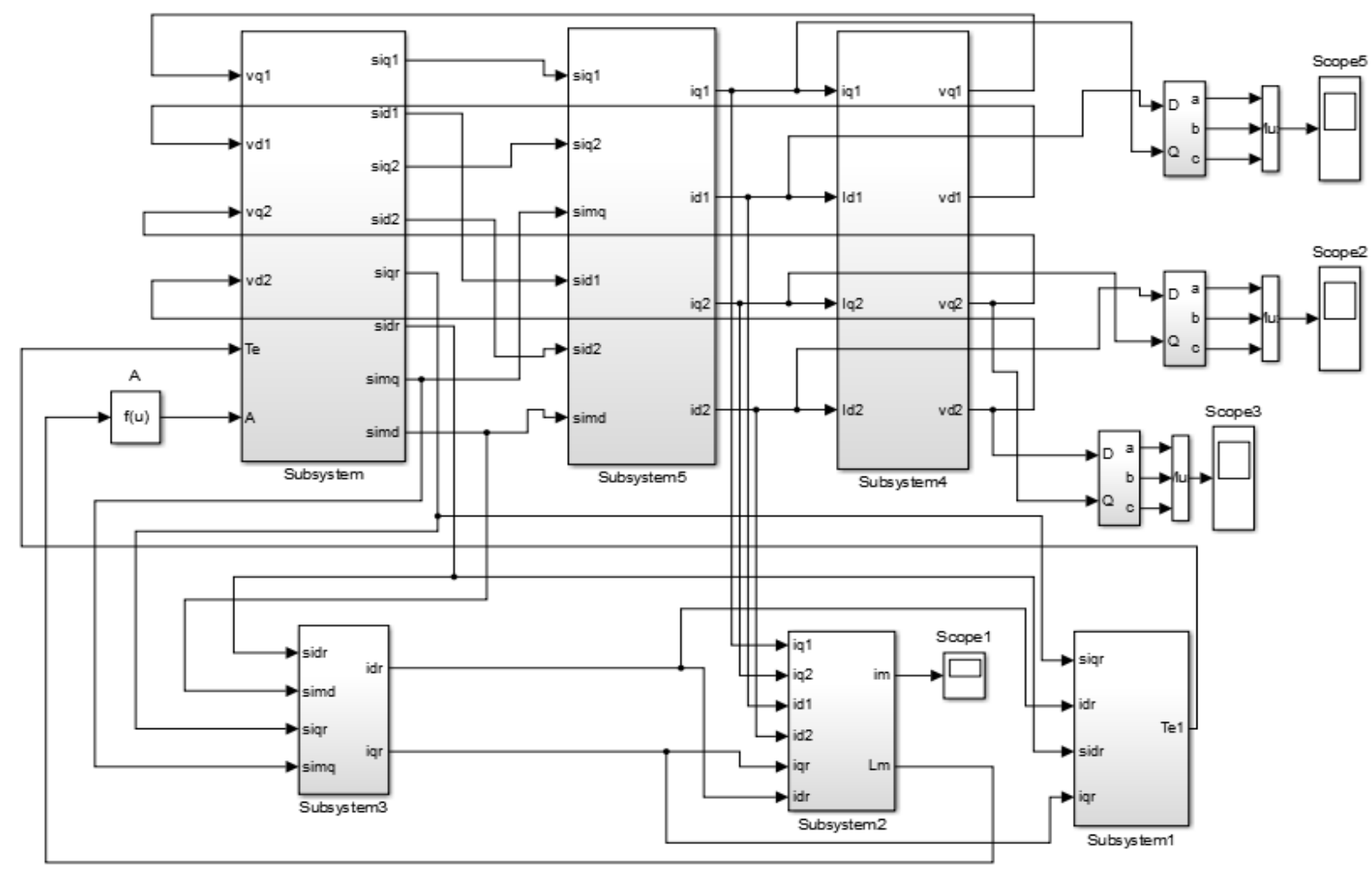

Fig.4.Matlab Simulink model of a stand alone six-phase induction generator for power generation

\section{A. Voltage and current build-up at No Load}

Fig. 5(a) and Fig.5(b)shows the simulated analytical current and voltage characteristics during no-load .In the present analysis.The per phase value of the capacitance is selected as

$90 \mu \mathrm{F}$.The voltage generated is about $200 \mathrm{~V}$ (rms) at rated speed of $1500 \mathrm{rpm}$. The terminal voltage and current rise from their

initial value of small volts and amperes to their steady state values. The magnitude no-load voltage and current rise depend

upon the value of capacitance and the level of magnetism in the rotor circuit of the self excited induction generator. Under steady state the machine develops about $200 \mathrm{~V}$ (rms) at no load condition.

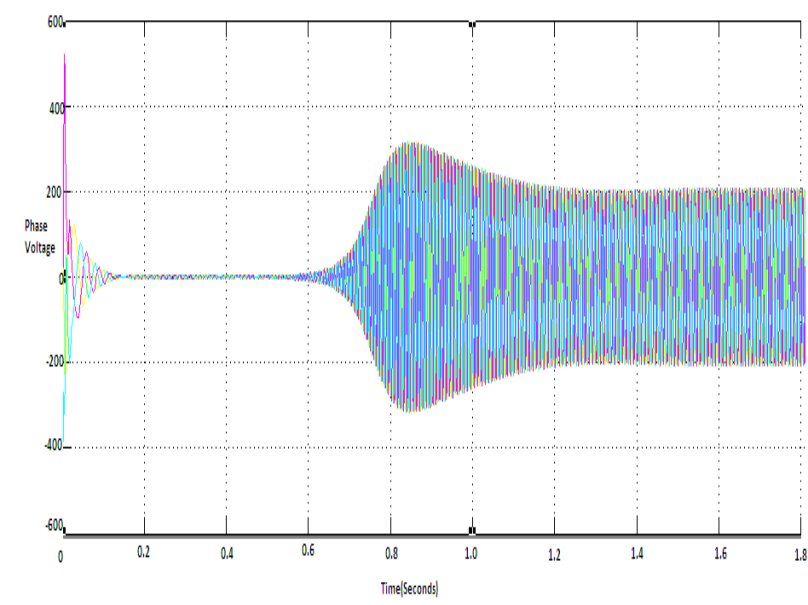

Fig.5(a).Voltage characteristicsof a self excited induction generator operating in six phase mode six phase under no load condition

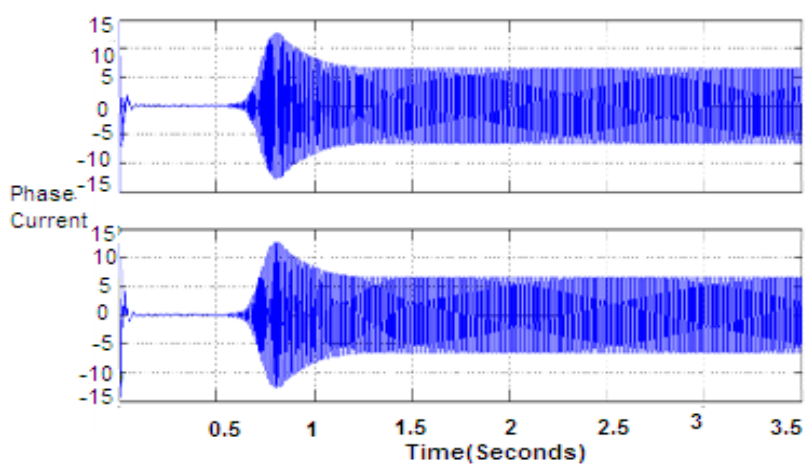

Fig.5(b).Current characteristics of a self excited induction generator operating in six phase mode under no load

B.Response of connection of a resistive load

Fig.6(a) and Fig.6(b) shows the voltage and current waveform of six phase self-excited induction generator terminal voltage and load current waveforms respectively, when connected a resistive load of $200 \mathrm{ohm}$. A decrease in voltage is seen in the self-excited induction generator operating in six phase mode which also causes a reduction in the capacitor current, which further reduces the voltage across the self-excited induction generator operaing in six phase mode.Due to reduction of reactive power supply the voltage regulation of the self-excited induction generator in this mode of operation is poor. 


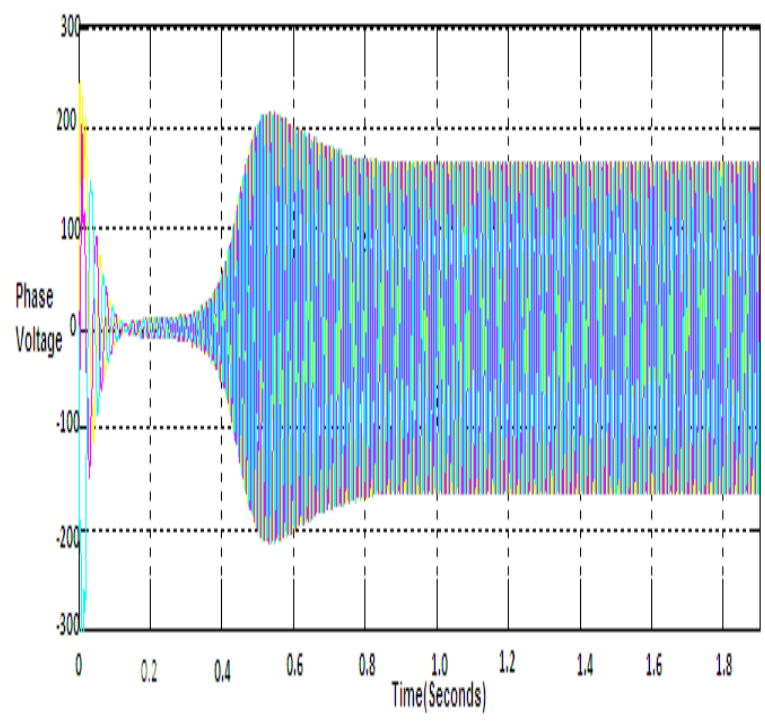

Fig.6(a).Voltage characteristics of a self excited induction generator operating in six phase mode under resistive load condition

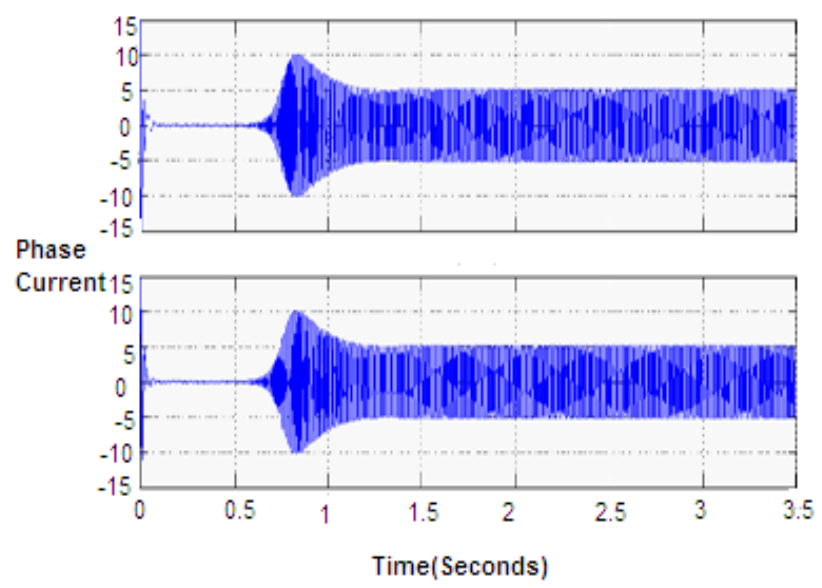

Fig.6(b).Current characteristics of a self excited induction generator operating in six phase mode under resistive load

\section{CONCLUSION}

In this paper the mathematical model of the self- excited induction generator operating in six phase mode has been simulated for studies on the performance of the machine. The paper depicts the simulated results for six-phase SEIG under different conditions. The main focus is placed on exploring the possibility of supplying two separate three-phase loads, which has the added advantage that the fault on one of the two stator winding sets does not lead to complete shutdown, as long as the other set is healthy. A required combination of capacitances are necessary to operate the machine at a desired level of voltage regulation, while keeping the induction generator terminal current and voltage magnitudes within its rated values. It is observed from the performance of SPSEIG under balanced load and excitation that the terminal voltage and current are balanced. The simulated results show a good performance and efficiency of the global SEIG conversion system.

\section{APPENDIX}

The parameters of the six phase self-excited induction generator used are as follow:
Resistances in the stator winding: $\mathrm{r}_{1}=\mathrm{r}_{2}=1.85 \mathrm{ohm}$,

Leakage inductances in the stator winding :

$\mathrm{L}_{11}=\mathrm{L}_{12}=0.013 \mathrm{H}$,

Resistance in the rotor winding: $\mathrm{r}_{\mathrm{r}}=2.25 \mathrm{ohm}$,

Leakage inductance in the rotor winding: $\mathrm{Llr}=0.013 \mathrm{H}$,

$\mathrm{Llm}^{\prime}=0.011 \mathrm{H}, \mathrm{J}=0.03 \mathrm{Kg} / \mathrm{m}^{2}$

$\mathrm{a}=0.14, \mathrm{~b}=0.001, \mathrm{c}=-0.001$, and $\mathrm{d}=0.00005$

\section{ACKNOWLEDGEMENT}

The authors are thankful to All India council of Technical Education, Ministry of Human Resources Development (MHRD), Govt. of India for providing financial assistants to do the research work.

\section{REFERENCES}

[1] Singh, G.K.: 'Self excited induction generator research-a survey 'Electrical Power system Research.vol 69,pp-107114,2004

[2] B.Singh, L.Shridhar and C.S.Jha, Improvements in the performance of self-excited induction generator through series compensation, IEEE Transactions on Energy Conversion, VOL. 25, NO. 2, June 2010

[3] Ali Nesba, Rachid Ibtiouen, Omar Touhami, “ Dynamic Performances of Self-Excited Induction Generator Feeding Different Static Loads", Serbian Journal of Electrical Engineering Vol. 3, No. 1, June 2006, 63 - 76

[4] Singh, G.K.: 'Multi-phase induction machine drive research - a survey', Electrical. Power Syst. Research., 2002, 61, pp. $139-147$

[5] E. A. Klingshirn," High phase order induction motors-Part I: experimental results," IEEE Trans. Power Applications Systems, vol. 102, pp. 54-591, 1983

[6] E.A. Kligshirn," High phase order induction motors-Part-IIExperimental results", IEEE Trans. PAS-102 (1) (1983) 54-59.

[7] Singh, G. K., Yadav, K. B., and Saini, R. P., "Modeling and analysis of multi-phase (six-phase)self-excited induction generator," Proc. IEEE Conf. The Eighth International Conference on Electrical Machines and Systems, ICEMS'05, Vol. 3, pp.1922-27, September 27-29, 2005.

[8] Singh, G. K., Yadav, K. B., and Saini, R. P., "Analysis of a saturated multi-phase (six-phase) selfexcited induction generator," International Journal of Emerging Electric Power Systems, Vol. 7, pp.1-23, 2006.

[9] Singh, G. K., Yadav, K. B., and Saini, R. P., "A Selfexcited six-phase induction generator for stand-alone renewable energy generation," Proc. IEEE International Agean Conference on Electric Machines, Power Electronics and Electromotions, ACEMP'07, pp. 690-695, Bordrum, Turkey, 10-12 September, 2007. 